\title{
Prawo rzymskie jako wskaźnik otwartości środowiska prawniczego? Panorama głębokiej europejskiej prowincji intelektualnej
}

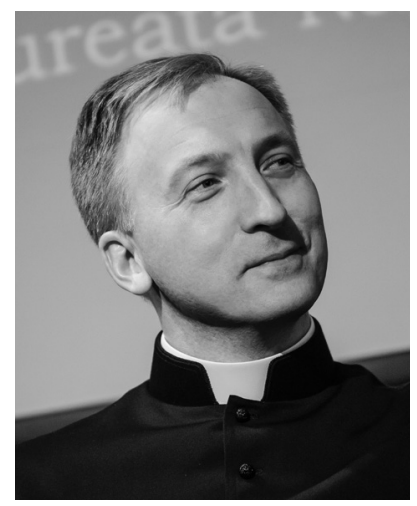

\section{ks. Franciszek Longchamps de Bérier}

Profesor nauk prawnych, LL.M. Georgetown, kierownik Katedry Prawa Rzymskiego na WPiA UJ, wybrany na czwarta kadencję do Komitetu Nauk Prawnych PAN, członek komisji prawnej Konferencji Episkopatów Unii Europejskiej (COMECE), zasiada we Wspólnym Komitecie Zarzadzajacym China-EU School of Law w China University of Political Science and Law w Pekinie.

$\square$ f.lb@uj.edu.pl

https://orcid.org/00oo-0002-1485-0976

\section{Measuring the Openness of Lawyers' Minds by Roman Law? Panorama of a Far European Intellectual Province}

\begin{abstract}
What is the purpose of a study to present comprehensively the condition and social impact of civil law lawyers in 18th century England? The study provides a broad panorama of a far European province, particularly in relation to its legal and intellectual character. A province is an intellectual, not a geographical term. Yet, the panorama should not be art for art's sake. A comparative study based on it might be instructive, if a legal researcher following it becomes well acquainted with the foreign jurisdiction and its legal history. There will always be a need for learned diagnoses and for the openness of lawyers' minds. A study of Roman law, if introduced and exercised as practical legal history, has proven to provide a very useful measure of diagnostic accuracy and to overcome provincial thinking in law.
\end{abstract}

Słowa kluczowe: historia nauczania prawa, prawo rzymskie, metodologia nauk prawnych

Key words: history of legal education, Roman law, methodology of legal research

https://doi.org/10.32082/fp.v6i56.288

Uniwersytety w Oksfordzie i Cambridge elektryzują świat akademicki już samymi nazwami. Dziś dzieje się tak głównie dlatego, że znalazły się w ścisłych czołówkach wszelkich rankingów wyższych uczelni świata. Nawet prawnicy szczerze się interesują tymi ośrodkami ${ }^{1}$, choć prawnicze wykształcenie jest w większości

\footnotetext{
1 Ł.J. Korporowicz, Prawo rzymskie $w$ Anglii w XVIII wieku. Nauczanie, studia, nauka, Łódź 2019.
} 
lokalne, a masa koncepcji prawnych silnie powiązana $\mathrm{z}$ kulturą ${ }^{2}$. Prawo działa i jest interpretowane w ramach danego kraju lub nawet węziej, bo w którejś $\mathrm{z}$ istniejących w nim kilku jurysdykcji. Służące danej jurysdykcji nauka i nauczanie prawa z natury swej muszą więc zachowywać lokalny charakter. Zastanawia zatem edukacyjny sukces renomowanych ośrodków kowzroczności środowiska prawniczego? Przykład wydaje się o tyle obiecujący, że na Wyspach zawsze mocno się trzymały prowincjonalne i skierowane do wewnątrz tradycje intelektualne ${ }^{6}$.

Nauka i nauczanie prawa w Oksford i Cambridge żyły do pierwszej połowy XVI w. uniwersalizmem niepodzielonej, katolickiej Europy. Ośrodki uniwersy-

\section{Prowincja to określenie intelektualne,}

\section{a nie geograficzne.}

anglosaskich i ich rosnący wpływ na świat prawni$\mathrm{czy}^{3}$ mimo jego podziału na dwie planety: common law i civil law. Czy sukces ten jest zagrożeniem dla europejskiej tradycji prawnej w tym jej nurcie, który ceni sobie szczególnie spuściznę prawa rzymskiego? O ile amerykańskie uczelnie nie mają tradycji uczenia owego prawa, o tyle wymienione na wstępie uniwersytety angielskie cenią je sobie również obecnie, choć wydaje się, że pozostaje tam ono na marginesie nauczania. Mniej marginalna okazała się rola prawa rzymskiego w orzeczeniach Izby Lordów wydawanych przez ostatnie wieki ${ }^{4}$. Czy angielski przykład pozwala uznać rozwój nauki i nauczania prawa rzymskiego ${ }^{5}$ w jednostkach kształcenia przyszłych elit za miernik bądź wskaźnik intelektualnej otwartości lub dale-

2 W. Twining, Diffusion and Globalization Discourse, „Harvard International Law Journal” 2006, t. 47, nr 2, s. 510.

3 F. Longchamps de Bérier, Common law a dekodyfikacja i globalizacja prawa (w:) F. Longchamps de Bérier (red.), Dekodyfikacja prawa prywatnego w europejskiej tradycji prawnej, Kraków 2019, s. 42-47.

4 Ł.J. Korporowicz, Prawo rzymskie w orzecznictwie Izby Lordów w latach 1876-2009, Łódź 2016.

5 Por. H. Kupiszewski, Droit romain - science et didactique (w:) W. Wołodkiewicz, M. Zabłocka (éds.), Le droit romain et le monde contemporain. Mélanges a la mémoire de Henryk Kupiszewski, Varsovie 1996, s. 163-173; F. Longchamps de Bérier, Roman Law and Legal Knowledge - Law Faculties versus Law Schools (w:) T. Giaro (ed.), Roman Law and Legal Knowledge. Studies in Memory of H. Kupiszewski, Warszawa 2011, s. 14 . teckie przejęły spuściznę prawa kanonicznego, a z nią szacunek dla nauczania prawa rzymskiego. W XVII w. Arthur Duck, piszący w oblężonym Oksfordzie swe dzieło komparatystyczne siatką prawa rzymskiego, miał jeszcze nadzieję na Europę jako swoistą wspólnotę chrześcijańskich użytkowników prawa rzymskiego ponad podziałami politycznymi i religijnymi ${ }^{7}$. Sytuacja w wieku XVIII znacznie się pogorszyła, co zbadał ostatnio szczegółowo Łukasz Jan Korporowicz. Wyniki poszukiwań przedstawił w nieobszernej książce ${ }^{8}$ - „do połknięcia” w dwa wieczory nawet przez kogoś, kto nie czyta zbyt szybko. Głównym powodem, dla którego czytelnik łatwo i szybko zdoła książkę pochłonąć, nie jest mała liczba stron, lecz styl: została ona napisana zgrabnie i ciekawie. Autor zadbał o wartką narrację i dobry język. Godne to wszystko uznania, bo świetna forma posłużyła przedstawieniu wyników mozolnych badań, których inna prezentacja mogłaby się okazać zupełnie niestrawna.

Podstawowym celem opracowania stało się „całościowe przedstawienie kondycji oraz społecznego oddziaływania środowiska cywilistów w osiemnastowiecznej Anglii”’ W W cytowanych słowach kryje się teza

6 W. Twining, Diffusion..., dz. cyt., s. 510.

7 Ł. Marzec, Między Rzymem, Dunajem a murem Hadriana. Prawo rzymskie i Europa $w$ De Usu et Authoritate Iuris Civilis Romanorum in Dominiis Principum Christianorum (1653) Arthura Ducka, Kraków 2017, s. 196.

8 Ł.J. Korporowicz, Prawo rzymskie w Anglii..., dz.cyt.

9 Tamże, s. 12. 
wewnętrzna, że środowisko owych cywilistów wpływ jakiś wywierało, choć nie wiadomo, czego w istocie oczekiwać: nie wiadomo, na kogo miałoby wywierać ten wpływ ani w jakiej perspektywie geograficznej Wyspy Brytyjskie, kolonie, Europa kontynentalna? Tez trzeba się doszukiwać znaczniej wytrwalej lub samemu je stawiać, gdyż w książce się ich niestety jasno nie formułuje. Mało przekonujący do podzielenia entuzjazmu dla zamierzeń całościowego „przedstawienia kondycji” wydaje się sam fakt, że „cywilistyka angielska XVIII wieku pozostawiła po sobie bogaty materiał źródłowy i literacki" ${ }^{10}$. Prawda, że na szczęście dla materiału jest on w języku powszechnie dziś znanym. Czy na szczęście dla tejże cywilistyki? Tego się dopiero dowiadujemy z książki. Dlaczego jednak wybór padł na tę epokę i ten tylko fragment Wysp Brytyjskich? A Szkocja zapatrzona w prawo rzymskie? Wszystko to dopiero początek problemów z zarysowaniem lub właściwym ustawieniem kwestii oczekiwanych wyników badań. Pytanie o cel naukowy samego opisu kondycji narzuca się zawsze z całą oczywistością.

Nie wiemy, dlaczego XVIII w. został wyznaczony datami kalendarzowymi. Nie wskazano w książce konkretnych zdarzeń, które czyniły z niego epokę. Możemy się domyślać, a potem o tym czytamy i wnioskujemy z pasji pisarskiej, że Ł.J. Korporowicz po prostu lubi Anglię. A wybrał okres, o którym nie napisano. Chciał zapełnić lukę, choć trzeba pamiętać, że takie zapełnianie nigdy nie powinno być celem samym w sobie. Należy też brać zawsze pod uwagę nieco przewrotną, ale otrzeźwiającą myśl, że skoro o czymś dotąd nie pisano lub zbyt wiele czasu nie poświęcono na badanie tego, może nie było warto. Bez wątpienia lubi Ł.J. Korporowicz pisać o prawie i prawnikach Anglii. Dlaczego jednak luki w badaniach nad prawem rzymskim w XVIII w. nie zapełnili dotąd lokalni uczeni, którzy archiwa oraz biblioteki mają pod ręką i nie muszą, prócz czasu na ich studiowanie, poświęcać go sporo na daleką podróż? Zwłaszcza historycy prawa z Oksfordu i Cambridge - pisaliby wtedy o historii swych almae matres. Jeśli jednak takiej pracy podejmuje się obcokrajowiec, narzuca się kolejna wątpliwość: dlaczego jego książka nie została ogłoszona drukiem po angielsku? Nie znajduję merytorycznego uzasad-

10 Tamże, s. 13. nienia dla publikowania wyników tak solidnie przeprowadzonych badań po polsku. Tematyka, choćby z powodów „patriotycznych”, powinna zainteresować świat prawniczy Anglii, jego lokalnych historyków, a także wydawców. Tego przynajmniej należałoby się spodziewać. Podstawowe jednak zastrzeżenie co do celu zarysowanego tak, jak uczynił to autor książki, dotyczy problemu, że przedstawienie, nawet całościowe, nie wnosi nic istotnego do nauki, jeśli precyzyjnie nie określimy, czego poprzez panoramę poszukujemy.

Czytelnik musi wreszcie zapytać, czy jest to książka o prawie, czy o historii. Ten dylemat nie daje się zbyć płaskim stwierdzeniem, że jest to wtedy opracowanie z zakresu historii prawa, bo może to raczej tylko historia nauczania, a o samym prawie niczego się nie dowiemy ${ }^{11}$. Lektura książki nie ułatwia też moim zdaniem odpowiedzi na kolejne pytania, czy autora bardziej interesuje Anglia, czy prawo rzymskie. Zbycie tego kolejnym płaskim stwierdzeniem, że zajmują go oba zagadnienia, wydaje się niebezpieczne, bo może prowadzić do sugestii, że jest najlepszym anglistą wśród romanistów, a romanistą wśród anglistów. Wszystkie powyższe wątpliwości wynikają przede wszystkim z wrażenia, które powstaje przy lekturze: autora książki zdaje się nie zastanawiać, co wiek XVIII w Anglii wnosi do prawoznawstwa; natomiast zakłada chyba, że do nauki prawa rzymskiego nie wnosi nic istotnego.

Systematyczny i szczegółowy opis prowadzony przez wszystkich pięć rozdziałów uzmysławia, jak dokładne przeprowadzono dla napisania książki poszukiwania źródłowe i biblioteczne. Czasem autor bawił się z powodzeniem - w prawdziwego detektywa, choć w sprawach angielskich, a nie szkockich. Znajdujemy wiele szczegółów, na które słusznie zwrócił uwagę, wyrabiając przy tym w czytelniku przekonanie, że ma przed sobą solidną pracę naukową, choć niemal w beletrystycznej formie. Niedosyt pozostawiają konkluzje, których na próżno szukać pod koniec każdego z rozdziałów - może z wyjątkiem czwartego. Mało konkretne wydaje mi się zakończenie książki, ale to bardzo subiektywna kwestia. Natomiast tekst rozdziałów pełen jest dojrzałych, kompetentnych i cie-

11 Por. F. Longchamps de Bérier, Rachunek sumienia dla historii prawa?, „Forum Prawnicze” 2010, nr 2, s. 93. 
kawych, a czasem zabawnych, wręcz plotkarskich uwag szczegółowych.

Praca wydaje się być wyrazem szacunku autora dla prawa rzymskiego i jego znaczenia dla prawoznawstwa w różnych epokach dziejów europejskiej tradycji prawnej. Mieści się w niej - jak widać z publikacji prawo obowiązujące w Anglii wieku XVIII. Tak tedy „twierdzenie, że cywiliści angielscy stanowili dodatek czy wręcz aneks do bogatej tradycji prawa angielskiego,
Książka rzeczywiście przedstawiła panoramę prawną Anglii XVIII w., a uczyniła to z perspektywy formacji prawniczej, która czerpie z prawa rzymskiego. Czasem panorama ta wydaje się ukazana trochę w trybie anegdoty, a nie poważnego pytania o prawoznawstwo, ale to nurt obecny w polskiej romanistyce. Wszelako bez wątpienia panorama jest w pełni udokumentowana, szczegółowa, sprawnie komentowana i wygląda na wyczerpującą.

\section{Czy romanistyczna formacja prawnicza}

\section{i klasyczne wykształcenie były niezaprzeczalnymi atutami w Anglii XVIII stulecia?}

należy odrzucić i uznać za zupełnie nietrafione"12. Jednak czytam i ostatnie słowa książki o absolwentach angielskich uniwersytetów: „posiadanie przez nich klasycznego wykształcenia oraz romanistyczna formacja prawnicza były niezaprzeczalnymi atutami"13, ale nie znajduję w pracy Ł.J. Korporowicza treści, które pozwalałyby uzasadnić wiarę $\mathrm{w}$ te niezaprzeczalne atuty. Tu wraca bowiem pytanie o cały kontekst społeczny. Jak zresztą badać wpływ cywilistów na ich otoczenie? A może zacytowane ostatnie słowa książki stanowią wyraz nadziei autora, która dotyczy nie tyle XVIII w., lecz jest programowym przekonaniem na każde czasy? Przekonanie to w pełni podzielam! Przyłączam się i chętnie będę ten fragment przywoływał w przyszłości. Wciąż jednak nie wiem, co wynika z tego, że ówczesne elity angielskie poważnie zasilali absolwenci prawa. Tak jest od dawna prawie wszędzie pojmujemy to zresztą intuicyjnie, ale warto byłoby określić, kogo uważać za elitę w danym czasie i miejscu. Podobnie chętnie cytował będę zdanie o równie uniwersalnej treści: „Studiowanie prawa rzymskiego często postrzegane było jako forma intelektualnego wyzwania"14.

12 Ł.J. Korporowicz, Prawo rzymskie w Anglii..., dz. cyt., s. 211.

13 Tamże, s. 212.

14 Tamże, s. 121.
Najcenniejsze, że ukazał się obraz głębokiej europejskiej prowincji, w szczególności prawniczej i intelektualnej. Na uniwersytetach Oksford i Cambridge studiowali wtedy tylko mężczyźni pochodzący z Anglii i Walii ${ }^{15}$. Przedstawiona przez autora nędza przeprowadzanych tam egzaminów z prawa ${ }^{16}$ pogłębia wrażenie stale obniżającego się poziomu. Jak więc absolwenci mieliby wpływać na innych? Jaką elitę mogliby następnie zasilać? A dowodzi dalej Ł.J. Korporowicz, że Anglicy właściwie nie jeździli na studia za granicę $e^{17}$. Przytacza znamienny przypadek, w którym odbycie podróży po Europie uznano za ważny argument na rzecz zawodowego przygotowania prawnika ${ }^{18}$. Pewnie, lepiej był obeznany ze światem i miał większe doświadczenie życiowe niż reszta, co nosa poza angielską chatkę nie wychyliła. Wykazywane przez autora książki uzależnianie nominacji profesorskich od zewnętrznych wpływów ze strony dworu czy rządu ${ }^{19}$ pogłębia najgorsze wrażenia dotyczące świata akademickiego - tutaj akurat angielskiego w XVIII stuleciu.

\footnotetext{
15 Tamże, s. 122.

16 Tamże, s. 82-83.

17 Tamże, s. 128.

18 Tamże, s. 67.

19 Tamże, s. 19.
} 
W nauczaniu, zamiast przedstawiać egzegezę „Digestów" justyniańskich, ułatwiano sobie sprawę, zajmując się w ich miejsce „Instytucjami” Justyniana. Pisze Ł.J. Korporowicz w swej książce: „Nie publikowali opracowań naukowych" ${ }^{20}$. To już nie prowincja, lecz pustynia. Nie wiemy tylko, czy w jego opinii pisanie panegiryku na cześć prawa rzymskiego ${ }^{21}$ to przejaw romanizmu ${ }^{22}$, czy pobieżnej, wyrywkowej znajomości ze strony prowincjusza. Może więc jeszcze nie pustynia, lecz tylko dzikie pola? Autor książki wspomina o pracy A.C. Schomberga ${ }^{23}$, który opisał wpływ rodyjskiego prawa na kształt prawodawstwa morskiego całej Europy: „co pozwala określić go mianem jedynego w XVIII wieku angielskiego autora, który w udany sposób podjął się omówienia zagadnienia z pola recepcji praw starożytnych" ${ }^{24}$. Jedynego! Samotna wyspa pośród burzanów. W książce Ł.J. Korporowicz odnotował prowadzenie dociekań naukowych przez prawników i wykładowców prawa, ale stan lub poziom czytelnictwa cywilistów, który stawia ich w „niezwykle złym świetle”27.

Może dlatego nikt na Wyspach nie chciał zapełniać luki z wieku XVIII, a książka Ł.J. Korporowicza wydana po angielsku lub przetworzona na artykuły wydrukowane w tym języku nie spotkałaby się z ciepłym przyjęciem. Przypomina mi się tu szczere zdziwienie Davida Pugsleya, gdy usłyszał o dwóch wojnach burskich w Afryce Południowej. W angielskiej szkole uczono go tylko o jednej. Nie dziwota - zauważył „uczyli nas o drugiej, bo pierwszą przegraliśmy”. Może więc rzeczywiście obcokrajowiec musiał się zająć pracą o historii - jak się okazało - bardziej nauczania niż nauki (bo ta, ostrożnie mówiąc, tam nie kwitła) prawa rzymskiego w Anglii XVIII w.? A ponieważ to prowincja, ogłaszano na Wyspach słabe publikacje i Ł.J. Korporowicz słusznie miał kłopoty z opisywaniem ich innowacyjności. Szkoda, że nie poczynił ustaleń, czy i jak dokonywanie przekładu na angielski łacińskich

\section{$\mathrm{Na}$ uniwersytetach Oksford i Cambridge studiowali tylko mężczyźni, tylko pochodzący z Anglii i Walii.}

na innych polach badawczych ${ }^{25}$ : nie podejmowali ich więc w zakresie prawa rzymskiego ani choćby prawa obowiązującego w Anglii. Natomiast pokazał autor typowe dla każdych czasów nowożytnych zjawisko, że nauczający prawa poświęcają się bardziej praktyce prawnej niż sprawom nauki lub akademickim ${ }^{26}$. Do pełni obrazu prawniczej prowincji dochodzi jeszcze

20 Tamże, s. 157.

21 Tamże, s. 178.

22 R. Orestano, Diritto romano, osobno opublikowane hasło z encyklopedii Novissimo Digesto Italiano, Torino 1960, s. 4-5.

23 A.C. Schomberg, A Treatise on the Maritime Laws of Rhodes, Oxford 1786

24 Ł.J. Korporowicz, Prawo rzymskie w Anglii..., dz. cyt., s. 201. Nie ceni jej B. Zalewski, Creative interpretation of lex Rhodia de iactu in the legal doctrine of ius commune, „Krytyka Prawa" 2016, t. 8, nr 2, s. 173-191.

25 Ł.J. Korporowicz, Prawo rzymskie w Anglii..., dz. cyt., s. 39. 26 Tamże, s. 22-23. źródeł ma się do stanu ówczesnej znajomości łaciny ${ }^{28}$. W swej pracy trafia zresztą na wiele niewiadomych, co umie pokazać w pełni naukowo - wszak negatywny też jest wynikiem; czasem mocniej wybrzmiewającym i łatwiejszym do zapamiętania.

Panorama ukazała głęboką europejską prowincję, naturalnie odciętą kanałem La Manche, w której oddalenie intelektualne i duchowe jeszcze się pogłębiło ze względu na istnienie Kościoła państwowego ${ }^{29}$, działającego właściwie bez zewnętrznych kontaktów. Ograniczonemu do Anglii chrześcijańskiemu związkowi wyznaniowemu służyli prawnicy wykształceni na uniwersytetach pomieszczonych w Cambridge i w Oksfordzie. Ci, ukształtowani przez kursy prawa

27 Tamże, s. 100.

28 Por. np. tamże, s. 160-161.

29 Por. T.J. Zieliński, Państwowy Kościół Anglii. Studium prawa wyznaniowego, Warszawa 2016. 
rzymskiego, działali prawie wyłącznie w sądach kościelnych oraz sądach Admiralicji ${ }^{30}$, co ich jeszcze bardziej alienowało. „Oxford i Cambridge były nie tylko miejscem studiów, lecz również sprawowania kultu religijnego Kościoła anglikańskiego"31. Zresztą prawie wyłącznie anglikanie tam studiowali.

Praca źródłowa badająca rozmaite przejawy obecności prawa rzymskiego w Anglii wieku XVIII ukazała głęboką prowincjonalność prawniczego środowiska przynajmniej z perspektywy romanistycznej. Dodajmy, że prowincja to określenie intelektualne, a nie geograficzne. Prowincjonalność nie mogła dobrze rokować prawu angielskiemu, które jak prawo polskie w tym samym czasie - także na rubieżach Europy, ale na drugim krańcu łacińskiego świata - „rozwijało się w sposób organiczny, miły sercu Savigny’ego i jego uczniów ze szkoły historyczno-prawnej”32. A dają się snuć domysły, że dalszy rozwój prawa polskiego wyglądałby podobnie lub równolegle do przemian angielskiego common law, gdyby nie zabory i przyniesione w ich czasie prawo rzymskie oraz czerpiące zeń i z prawa natury kodyfikacje. Jednak w przedrozbiorowej Polsce zdawano sobie sprawę z niebezpieczeństwa prowincjonalności, bo choć „dla ogółu prawników epoki saskiej prawo rzymskie odgrywało rolę ozdoby pozwalającej się popisać erudycją i odwołać się do bliskich szlacheckiej mentalności rzymskich tradycji”, niejednokrotnie i w sposób oświecony domagano się zreformowania systemu prawnego przy użyciu prawa rzymskiego, jak uczynił to na sejmie 1752 r. biskup płocki Antoni Dembowski ${ }^{33}$. Panorama zatem wystarczyć nie może, jak nie powinno się rezygnować z porównań, zwłaszcza gdy dogłębnie zna się cudze prawo, a na własnym jest się wychowany. Potrzeba uczonych diagnoz i jak zawsze potrzeba otwartości środowiska prawniczego.

30 Por. Ł. Marzec, Czy prawo rzymskie pokonato kanał La Manche?, „Krakowskie Studia z Historii Państwa i Prawa” 2008, nr 2, s. 49-51.

31 Ł.J. Korporowicz, Prawo rzymskie w Anglii..., dz. cyt., s. 129.

32 J. Kodrębski, Prawo rzymskie w Polsce XIX wieku, Łódź 1990, s. 10 .

33 Tamże, s. 22-23.
Należy wskazywać sprawdzone środki - w tym dla leczenia się z prowincjonalności w myśleniu o prawie. Zawsze dobrze służyło tym celom studium prawa rzymskiego, jeśli postrzegać je praktycznie. A czysto antykwarycznie uprawiano je na angielskich uniwersytetach w XVIII stuleciu.

\section{Bibliografia}

Kodrębski J., Prawo rzymskie w Polsce XIX wieku, Łódź 1990.

Korporowicz Ł.J., Prawo rzymskie w Anglii w XVIII wieku.

Nauczanie, studia, nauka, Łódź 2019.

Korporowicz Ł.J., Prawo rzymskie w orzecznictwie Izby Lordów w latach 1876-2009, Łódź 2016.

Kupiszewski H., Droit romain - science et didactique (w:) W. Wołodkiewicz, M. Zabłocka (éds.), Le droit romain et le monde contemporain. Mélanges a la mémoire de Henryk Kupiszewski, Varsovie 1996, s. 163-173.

Longchamps de Bérier F., Common law a dekodyfikacja i globalizacja prawa (w:) F. Longchamps de Bérier (red.), Dekodyfikacja prawa prywatnego w europejskiej tradycji prawnej, Kraków 2019, s. 19-51.

Longchamps de Bérier F., Rachunek sumienia dla historii prawa?, „Forum Prawnicze” 2010, nr 2, s. 88-95.

Longchamps de Bérier F., Roman Law and Legal Knowledge - Law Faculties versus Law Schools (w:) T. Giaro (ed.), Roman Law and Legal Knowledge. Studies in Memory of H. Kupiszewski, Warszawa 2011, s. 13-19.

Marzec Ł., Czy prawo rzymskie pokonało kanał La Manche?, „Krakowskie Studia z Historii Państwa i Prawa” 2008, nr 2, s. 43-54. Marzec Ł., Między Rzymem, Dunajem a murem Hadriana. Prawo rzymskie i Europa $w$ De Usu et Authoritate Iuris Civilis Romanorum in Dominiis Principum Christianorum (1653) Arthura Ducka, Kraków 2017.

Orestano R., Diritto romano, osobno opublikowane hasło z encyklopedii Novissimo Digesto Italiano, Torino 1960, s. 1-77.

Twining W., Diffusion and Globalization Discourse, „Harvard International Law Journal” 2006, t. 47, nr 2, s. 507-515.

Zalewski B., Creative interpretation of lex Rhodia de iactu in the legal doctrine of ius commune, „Krytyka Prawa” 2016, t. 8 , nr 2, s. 173-191.

Zieliński T.J., Państwowy Kościół Anglii. Studium prawa wyznaniowego, Warszawa 2016. 